\title{
Biological and physical coupling in the lee of a small headland: contrasting transport mechanisms for crab larvae in an upwelling region
}

\author{
Amber J. Mace*, Steven G. Morgan \\ Bodega Marine Laboratory, University of California at Davis, PO Box 247, Bodega Bay, California 94923, USA
}

\begin{abstract}
Delivery mechanisms for crab postlarvae along upwelling coasts have been inferred from weekly sampling, but more frequent sampling is needed to better relate highly variable oceanographic conditions to postlarval supply. Settlement of 8 crab taxa was measured in Bodega Bay, California every $2 \mathrm{~d}$ from 12 May through $3 \mathrm{July}, 2002$. Abundance of postlarval and juvenile settlers was cross-correlated with physical variables. Four upwelling and 4 relaxation events were recorded as fluctuations in wind stress and sea temperature during this period. Transitions to and from upwelling conditions in Bodega Bay were brief and temperature changes occurred rapidly. The strongest correlations between crab abundance and physical variables indicative of upwelling and relaxation conditions were observed for Cancer magister, which settled primarily during relaxation-favorable conditions, and for Cancer antennarius/productus, which settled primarily during upwelling-favorable conditions, suggesting interspecific differences in delivery of postlarvae to adult habitat. Weak correlations with upwelling-favorable conditions were observed for Pugettia producta/ richii and Pagurus spp. Settlement of Hemigrapsus nudus, Petrolisthes cinctipes, and P. eriomerus exhibited significant correlations with changes in tidal height. These results highlight the existence of multiple taxon-specific delivery mechanisms of closely related taxa in one small geographic region.
\end{abstract}

KEY WORDS: Headland $\cdot$ Larval retention $\cdot$ Meroplankton $\cdot$ Larval dispersal

\section{INTRODUCTION}

Identifying the biophysical mechanisms that deliver planktonic larvae to adult habitats is a critical step towards understanding community dynamics, particularly in recruitment limited regions where larval supply more strongly influences the distribution and abundance of adults (Connell 1985, Gaines \& Roughgarden 1985, Minchinton \& Scheibling 1991, Menge 2000, Connolly et al. 2001). Upwelling regions may be recruitment limited due to persistent offshore and equatorward flow (Connolly et al. 2001). In these regions dynamic and energetic physical oceanographic processes are strong determinants of dispersal and subsequent recruitment patterns (e.g. Roegner et al. 2003). Understanding the physical mechanisms that deliver planktonic larvae to adult habitats in upwelling regions has been the focus of numerous studies (Parrish et al. 1981, Farrell et al. 1991, Roughgarden et al. 1991, Graham et al. 1992, Yoklavich et al. 1996, Shkedy \& Roughgarden 1997, Pineda 1999, Lundquist et al. 2000, Botsford 2001, Wing et al. 2003).

Biophysical mechanisms that deliver crab postlarvae (megalopae) to nearshore habitats along the central California upwelling region have been postulated, though they have not been well resolved. Studies suggest that vertical migrations between layers of opposing flow direction enable larvae to regulate alongshore and cross-shelf movements (reviewed in Kingsford et al. 2002, Roughan et al. 2005). Ontogenetic shifts in depth preference may further facilitate the onshore transport of late-stage larvae by winds, internal waves, 
and other physical mechanisms (reviewed in Shanks 2002). Because multiple factors play a role in larval delivery to shallow water habitats, both interspecific and intraspecific differences in the timing of larval settlement may occur.

Although multiple mechanisms are likely at play, wind-driven coastal upwelling is typically identified as the primary forcing mechanism that regulates the movement of larvae along the central California coast. During upwelling, dense nutrient-rich water from depth meets lower density offshore water, sometimes forming a convergence zone at the leading edge of an upwelling front. Convergence zones (i.e. fronts) have been associated with an increased concentration of organisms (Grantham et al. 1995, Shanks et al. 2000), and the movement of these fronts during upwelling and relaxation has been identified as a mechanism for cross-shelf (Roughgarden et al. 1988, Farrell et al. 1991, Roughgarden et al. 1991) and alongshore (Wing et al. 1995b, 1998) movement of meroplankton. For example, the cross-shelf movement of upwelling fronts has been linked to barnacle recruitment (Farrell et al. 1991, Roughgarden et al. 1991). During active upwelling, surface waters carrying larvae are advected offshore via Ekman transport and larvae may be subsequently returned to shore by onshore flow when upwelling winds relax (Roughgarden et al. 1988, Farrell et al. 1991, Roughgarden et al. 1991).

Upwelling winds also transport warm surface waters equatorward, and the cessation of upwelling winds results in the poleward propagation of surface water (Send et al. 1987). Additionally, topographic features such as headlands provide shelter from upwelling winds, and have been shown to accumulate particles in their lee (Wing et al. 1995a, Mace \& Morgan 2006). Wing et al. (1995a) found that during upwelling, larvae accumulated in the lee of Point Reyes, a prominent headland just north of San Francisco Bay, California. Larval settlement at this site was temporally consistent and not strongly correlated with physical variables such as wind stress or temperature. Similarly, high settlement has been observed in the lee of a smaller headland $(<10 \mathrm{~km})$ (Mace \& Morgan 2006), indicating that this process is acting at multiple scales. During relaxation of upwelling winds, Wing et al. (1995a) observed increased settlement of postlarvae poleward of Point Reyes. Larval settlement was more episodic and well correlated with decreased wind stress and increased water temperature, which indicate the arrival of warm water from the lee of Point Reyes. Wing et al. (1995a) inferred that the main supply of propagules to the coastal region between Point Reyes and Point Arena (60 miles to the north) originates from this poleward propagation of surface water. This trend was most apparent during years with distinct upwelling and relax- ation cycles (Wing et al. 2003). However, sampling at a finer temporal scale is needed to determine mechanisms that influence larval transport during periods when oceanographic conditions are less distinct.

Because it is difficult to distinguish transport mechanisms when using data from weekly sampling, Wing et al. (1995a, 2003) were unable to resolve the influence of high frequency activities such as internal waves. Many studies have focused on upwelling processes on time scales of weeks to years (Farrell et al. 1991, Roughgarden et al. 1991, Graham et al. 1992, Botsford 2001, Wing et al. 2003), however larvae may also be concentrated and delivered via tidally forced internal waves with time scales of hours to days (internal tides) that form at the shelf break or around other complex bathymetric features such as ridges and submarine canyons (reviewed in Shanks 2002). Larvae that are concentrated in surface convergences associated with internal waves tend to be late stage larvae or postlarvae. Larvae delivered by internal waves may have temporal patterns of settlement that peak every 13 to $15 \mathrm{~d}$, corresponding with the spring-neap cycle (reviewed in Shanks 2002). Internal waves may be more frequent during relaxation events when the water column is more stratified (Rosenfeld 1990) and may be responsible for the observed correlations between settlement and the arrival of warm water during relaxation periods (Shanks 2002).

To better understand the possible forcing mechanisms that deliver larvae to the nearshore waters of central California, we sampled postlarval settlement every $2 \mathrm{~d}$ for $54 \mathrm{~d}$ during the peak settlement and upwelling season in 2002 (Wing et al. 2003, Mace \& Morgan 2006). To address potential delivery mechanisms, we compared $2 \mathrm{~d}$ averages of crab settlement with wind stress, temperature, salinity, tidal height, and a local upwelling index.

\section{MATERIALS AND METHODS}

Study system. This study was conducted in Bodega Bay, California, USA, which is characterized by persistent equatorward (upwelling favorable) winds during the spring and summer months. The study site is located just offshore of Pinnacle Rocks (PR) $\left(38^{\circ} 18.328^{\prime} \mathrm{N}\right.$, $123^{\circ} 01.435^{\prime} \mathrm{W}$ ) along the eastern shore of northern Bodega Bay (Fig. 1). Bodega Bay is located on the leeward side of a small headland and is a shallow, broad, southwest-facing embayment. The bay mouth is approximately $11 \mathrm{~km}$ wide from the northern tip at Bodega Head to the southern tip at Tomales Point. The rocky outcrops of Bodega Head and Tomales Point continue as a shallow ( $<15 \mathrm{~m}$ deep) submarine ridge across the mouth of the bay. The ridge rises to the surface to form Bodega Rocks toward the northern end of the bay. The bay is 20 

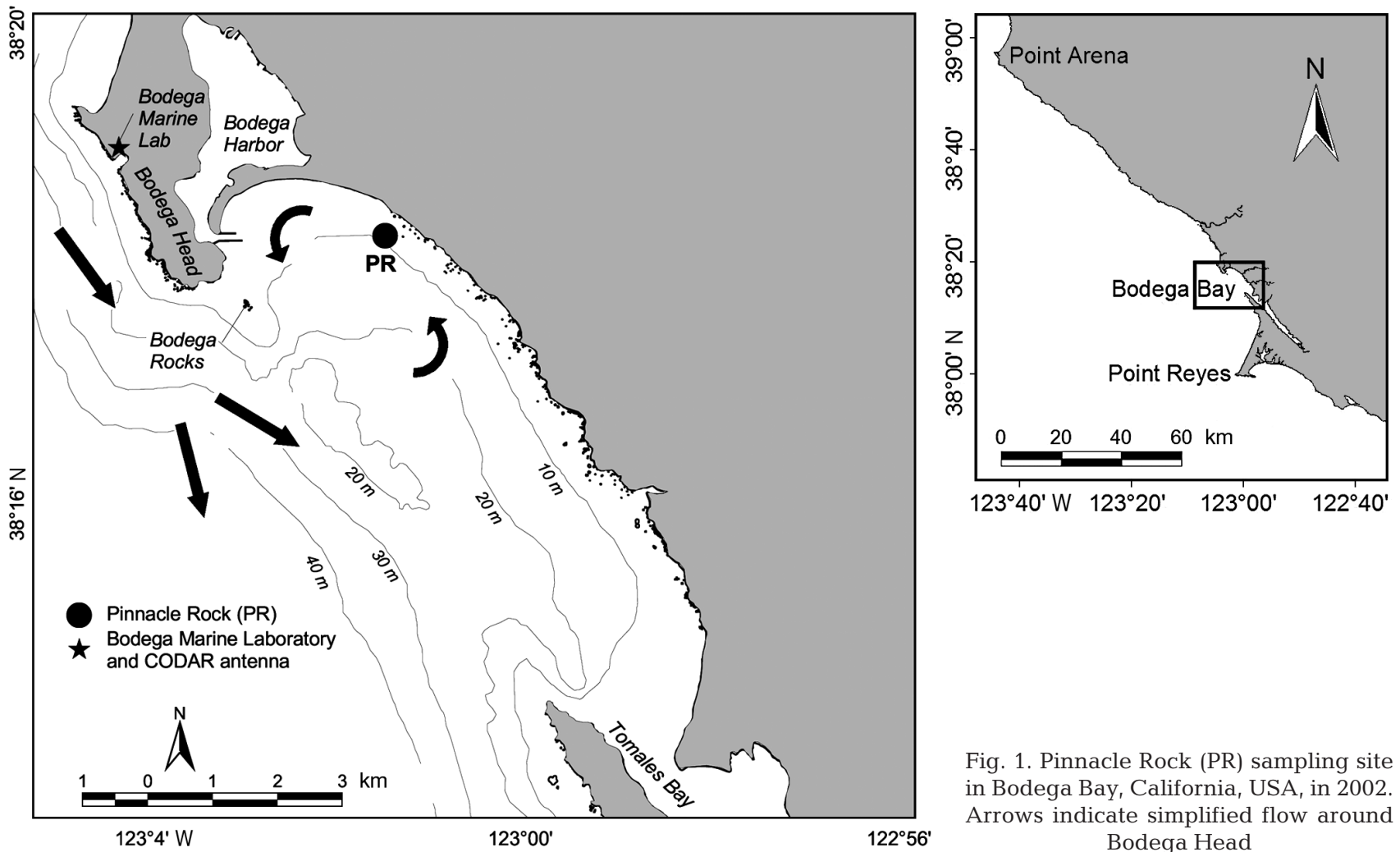

Fig. 1. Pinnacle Rock (PR) sampling site in Bodega Bay, California, USA, in 2002. Arrows indicate simplified flow around Bodega Head

to $25 \mathrm{~m}$ deep, and depths increase rapidly to more than $40 \mathrm{~m}$ seaward of the ridge. Tides are mixed semi-diurnal with a tidal range of 1.2 to $2.9 \mathrm{~m}$. A detailed study of circulation in the area is available in Roughan et al. (2005).

Settlement patterns depend in part on the timing of larval release and developmental period (Wing et al. 1995b). The crabs in this study spend weeks to months in the plankton, developing through 2 to 5 zoeal stages and a megalopal (postlarval) stage before returning to the benthos as juveniles. The timing of release and larval duration is not well known, but varies among taxa. Release of cancrid species along the California coast is estimated to occur between December and March (Reilly 1983, Strathmann 1987). December through March is characterized by seasonal strong winds from storm events, and a weakly poleward nearshore flow. In March and April, nearshore flow shifts equatorward, and upwelling conditions prevail (Largier et al. 1993). Cancrid settlement in Bodega Bay occurs year round but peaks in May and June while grapsid, majid, pagurid, and porcellanid settlement peaks between May and August (Mace \& Morgan 2006). Estimated larval periods for cancrid species (Cancer antennarius, C. productus and C. magister) are 36 to $>60 \mathrm{~d}, 68$ to $150 \mathrm{~d}$ and 75 to $180 \mathrm{~d}$ respectively (Reilly 1983, Strathmann 1987, Grantham et al. 2003, Shanks \& Eckert 2005). On the other hand larval durations for Hemigrapsus nudus, Petrolisthes cinc- tipes, Pugettia producta/richii, $P$. eriomerus and Pagurus spp. are 32,46,49,60, and 69 to 74 d, respectively (Grantham et al. 2003, Shanks \& Eckert 2005). Shorter estimated larval durations for non-cancrid crabs and settlement peaks that occur between May and August suggest that the majority of these species release their larvae when upwelling conditions prevail.

Oceanographic data. Hourly averages for the speed and direction of surface currents offshore of Bodega Bay were obtained from a high frequency radar system (CODAR) (http://bml.ucdavis.edu/boon/). CODAR data describe the speed and direction of the surface current over $2200 \mathrm{~km}^{2}$ area extending 50 to $70 \mathrm{~km}$ from shore with a resolution of $2 \mathrm{~km}$ (Kaplan \& Largier in press).

Offshore wind speed and direction were obtained from the National Data Buoy Center (NDBC 46013, $38^{\circ} 13^{\prime} 30^{\prime \prime} \mathrm{N}, 123^{\circ} 19^{\prime} 00^{\prime \prime} \mathrm{W}$; www.ndbc.noaa.gov/) and local wind velocities were obtained from a land-based site at the Bodega Marine Laboratory (BML, $38^{\circ} 19^{\prime} 03.35^{\prime \prime} \mathrm{N}, 123^{\circ} 04^{\prime} 17.20^{\prime \prime} \mathrm{W}$, http://bml.ucdavis. edu/boon/). Alongshore winds at BML and the NDBC buoy were significantly correlated with $\mathrm{r}=0.88$ at a lag of $2 \mathrm{~h}$ (BML leads NDBC) (Roughan et al. 2005). Wind data from the offshore buoy were used because they are more representative of larger scale wind forcing events. Along- and across-shore wind stress were calculated (Large \& Pond 1981) from $10 \mathrm{~min}$ averaged data that were adjusted to a height of $10 \mathrm{~m}$ above sea 
level using a neutral stability wind profile and rotated in the alongshore direction to a principal axis of $317^{\circ}$. Negative values of alongshore wind stress indicate equatorward winds, with larger negative values reflecting stronger upwelling-favorable winds. Low or positive values are associated with relaxation or downwelling conditions. Positive cross-shore wind stress indicates eastward (onshore) wind.

Upwelling indices (for $39^{\circ} \mathrm{N}, 125^{\circ} \mathrm{W}$ ) were obtained from the National Oceanic and Atmospheric Administration's Pacific Fisheries Environmental Laboratory (PFEL), Pacific Grove, California (www.pfeg.noaa. gov/). Positive values indicate upwelling and offshore transport of surface waters resulting from equatorward wind stress, whereas low values indicate relaxation of upwelling. Negative values indicate downwelling and the onshore advection of surface waters due to poleward wind stress.

Sea surface temperature (SST) was used as an indicator for upwelling (Shkedy \& Roughgarden 1997). In the present study, upwelling conditions were defined by SST at the study site of $<10^{\circ} \mathrm{C}$ in response to increased (negative) alongshore wind stress. Conversely, relaxation conditions were defined by SST $>10^{\circ} \mathrm{C}$. Continuous temperature data were taken from 2 Optic StowAway TidbiT ${ }^{\circledast}$ thermistors, which were placed on 1 settlement mooring at the site: $1 \mathrm{~m}$ off the bottom (approximately $9 \mathrm{~m}$ deep) and $1 \mathrm{~m}$ below the surface. Temperature $\pm 0.2^{\circ} \mathrm{C}$ was recorded every $6 \mathrm{~min}$. The difference between the maximum estimated tidal height for each $2 \mathrm{~d}$ sampling period (maximum tidal range) was obtained from tide prediction software (Tides and Currents v2.0a, Nautical Software). Daily averages of salinity \pm 0.005 psu were obtained from a Sea-Bird Electronics thermosalinograph (SBE 45 MicroTSG) located in the seawater intake line at BML (http://bml.ucdavis.edu/boon/). Average daily rainfall was recorded from the National Weather Service reporting station at BML using a Hydrological Services TB4 Tipping Bucket Rain Gauge.

Larval settlement. Larval settlement of benthic invertebrates was monitored at 1 site (PR) every $2 \mathrm{~d}$ from 12 May to 3 July 2002, yielding 26 samples over $54 \mathrm{~d}$. The sampling period was chosen to overlap with the peak settlement period of the species of interest (Mace \& Morgan 2006). The sampling frequency was chosen because previous settlement data collected weekly (Mace \& Morgan 2006) were inadequate to resolve potential transport mechanisms. The PR site was selected because it is relatively protected from adverse sea conditions, facilitating regular sampling and because it had consistently higher settlement than other sites in the area. Sampling also was attempted at a site along the exposed side of Bodega Head; however high seas prevented consistent sampling.
Three moorings, with settlement substrate attached $1 \mathrm{~m}$ below the surface, were deployed approximately $50 \mathrm{~m}$ apart running parallel to shore along the $10 \mathrm{~m}$ isobath at Pinnacle Rock (Fig. 1). Settlement substrate consisted of 2 mesh bags $(10 \times 30 \mathrm{~cm})$ containing 3 Tuffy $^{\circledR}$ kitchen scrub pads each. Collectors were deployed and retrieved every $48 \mathrm{~h}$, rinsed in fresh water, and settlers were fixed in $50 \%$ ethanol. Postlarvae and juveniles were identified to species when possible using available keys (Lough 1974, Shanks 2001). Cancer productus and C. antennarius were distinguished as juveniles but not as postlarvae. These species were collectively called Cancer antennarius/ productus, even though $79 \%$ of the juveniles were C. antennarius. Similarly, Pugettia producta and $P$. richii were not distinguished at the postlarval stage, although $95 \%$ of the juveniles collected were identified as P. producta.

Data analysis. Cross-correlations were calculated between time series for crab settlement and physical variables. Of the taxa investigated 7 of 8 were present $>80 \%$ of the time and had no significant autocorrelations, and only these 7 taxa were analyzed to limit the number of significant results due to an abundance of zeros. Settlement was monitored every 2 d for $54 \mathrm{~d}$ ( 26 trips) and $2 \mathrm{~d}$ averages of physical variables were cross-correlated with mean values of crab settlement from 3 moorings for each $2 \mathrm{~d}$ sampling period. Abundances were $\log _{10}$ transformed to meet the assumptions of normality and to help homogenize the variance so that the time series was more stationary and autocorrelation was less likely. No seasonal trends were apparent in the physical variables, thus de-trending was not necessary. Temperature at the bottom and the surface were highly correlated with each other $(0 \mathrm{~d}$ lag: $r=0.923)$; because settlement was monitored at the surface, only surface temperatures were used for time series analysis. For clarity, lags are presented in days in the text. The sign indicates whether peaks in settlement occurred after (positive) or before (negative) changes in the physical variables. Since the response variable of settlement must follow the physical predictor variables, only positive lags are reported, with the exception of cyclic environmental variables. Therefore, negative lags are reported for cross-correlations between settlement and maximum tidal range because of the predictable cyclic nature of tides. Only lags $\leq 6$ to $8 \mathrm{~d}$ are considered for this $54 \mathrm{~d}$ series because lags of 10 to $20 \%$ of the time series are considered valid (Emery \& Thomson 2001). Because correlations from brief time series may be due primarily to one event or only a few data points, we also qualitatively assessed whether the observed settlement patterns appeared to occur in response to changes in the physical environment. 


\section{RESULTS}

\section{Physical data}

The 2002 season was characterized by strong upwelling (Grantham et al. 2004, Mace \& Morgan 2006). During the sampling period, there were 4 upwelling and 4 relaxation events of varying lengths. Upwelling events ranged from 4 to $10 \mathrm{~d}$ with an average of $7.25 \pm 1.3 \mathrm{~d}$, SE. Relaxations were typically shorter and ranged from 3 to $4 \mathrm{~d}$, although one relaxation event lasted $14 \mathrm{~d}$ (19 May to 1 June; Fig. 2), thus the average was $6.25 \pm 2.6$ d, SE.
Positive values of the upwelling index (at $39^{\circ} \mathrm{N}, 125^{\circ} \mathrm{W}$ ) were correlated with negative (upwelling favorable) alongshore wind stress ( 0 to $2 \mathrm{~d}$ lag, $\mathrm{r}=-0.74$ ). As wind stress increased in the equatorward direction, so did the upwelling index. Surface water temperature was correlated with alongshore wind stress (0 to 2 d lag: $\mathrm{r}=0.752)$ and averaged $10.3 \pm 0.2^{\circ} \mathrm{C}(\mathrm{SE})$ with a range of 8.4 to $13.2^{\circ} \mathrm{C}$. When equatorward wind stress increased (larger negative values), temperature decreased as expected, indicating upwelling. Salinity stayed fairly constant between 33.6 and 33.8 during this period except on 21 May and 5 June, when it decreased to 32.9

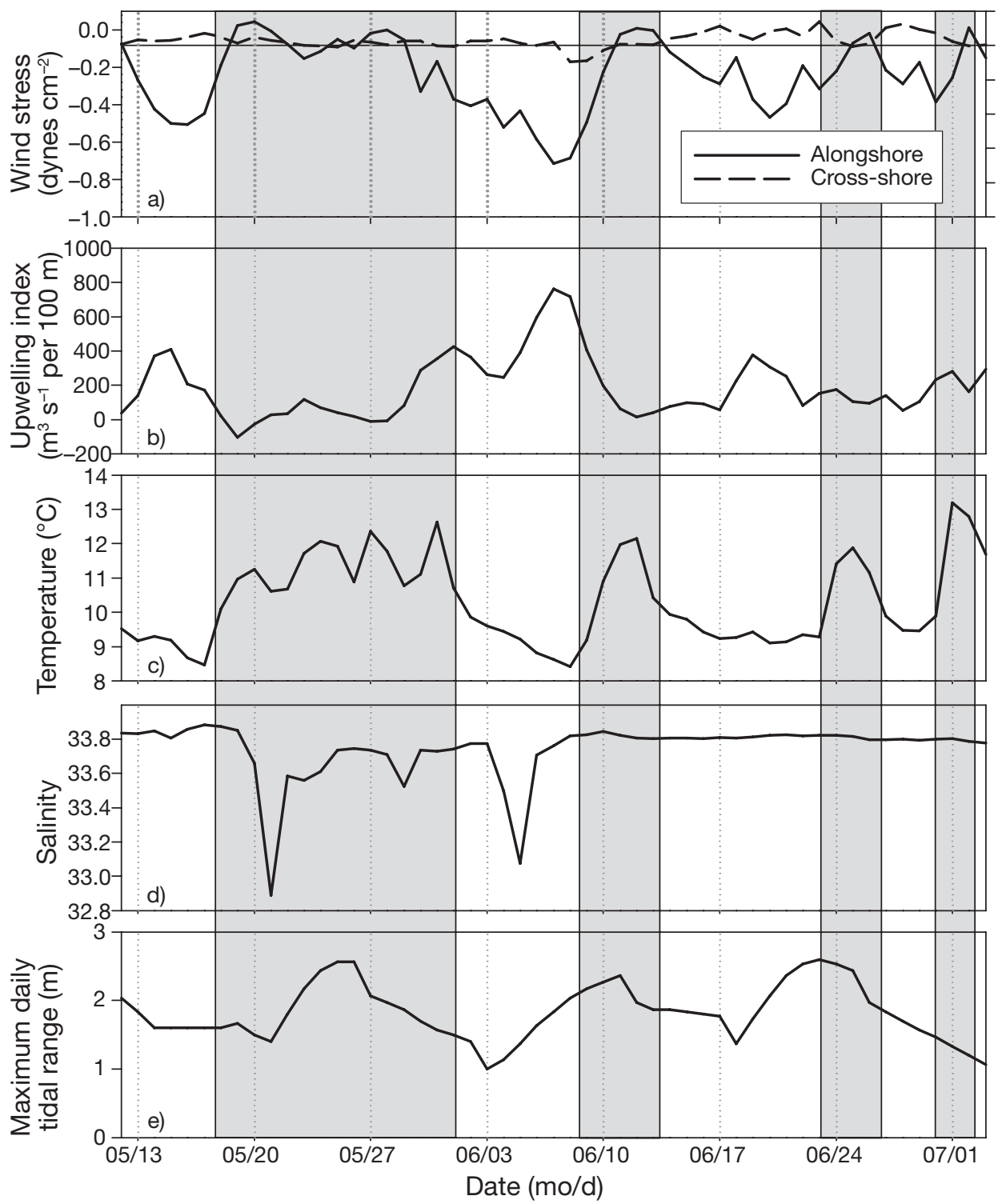

Fig. 2. Time series at Bodega Marine Laboratory from 12 May to 3 July 2002 of daily averages of (a) alongshore and cross-shore wind stress (dynes $\mathrm{cm}^{-2}$ ) rotated to $317^{\circ}$ (negative alongshore values indicate increasing equatorward wind stress); (b) Bakun upwelling indices for $39^{\circ} \mathrm{N}, 125^{\circ} \mathrm{W}\left(\mathrm{m}^{3} \mathrm{~s}^{-1}\right.$ per $100 \mathrm{~m}$ of coastline); (c) temperature $\left({ }^{\circ} \mathrm{C}\right)$ indicating transitions from upwelling $\left(<10^{\circ} \mathrm{C}\right)$ to relaxation $\left(>10^{\circ} \mathrm{C}\right)$ conditions; (d) salinity; and (e) maximum daily tidal range $(\mathrm{m})$. Shaded regions approximately represent relaxation events 
and 33.0 respectively (Fig. 2). Salinity was correlated with temperature and wind during 2002 (Mace \& Morgan 2006). Rainfall measuring 6.1 and $8.9 \mathrm{~mm}$ was recorded at BML on 19 and 20 May respectively. Because relaxation conditions prevailed during this time, the low salinity levels were likely due to poleward advection of lower-salinity waters from the Gulf of the Farallones and San Francisco Bay (Fig. 3a). However, only $0.2 \mathrm{~mm}$ of rain was recorded at BML on 4 and 5 June. Upwelling conditions prevailed during this time and the low salinity values observed may have resulted from the delivery of fresher water from the Russian River plume located north of Bodega Bay (Fig. 3b).

\section{Larval settlement}

Between 12 May and 3 July 2002, 8 crab taxa settled, and most of them settled during upwelling conditions (Table 1). Cancer antennarius/productus were present $96.2 \%$ of the time, but one large peak that occurred in June during upwelling favorable conditions accounted for $42 \%$ of total settlement (Fig. 4). CODAR data from this day show that this settlement peak occurred when surface currents in the region were moving predominately equatorward (Fig. 3b). Settlement of C. antennarius/productus was negatively cross-correlated with both surface water temperature and alongshore wind stress ( 0 to $2 \mathrm{~d}$ lag) indicating that settlement increased as temperature decreased and equatorward (upwelling-favorable) wind stress increased (Table 2). Overall, $90 \%$ of settlement of this taxon occurred during upwelling-favorable conditions (Fig. 5).

Cancer magister were present in $84.6 \%$ of samples, and most settled during relaxation conditions. Settlement in this species was positively cross-correlated with surface water temperature and alongshore wind stress (0 to $2 \mathrm{~d}$ lag). Thus, settlement increased as surface water temperature increased and equatorward wind stress decreased (Table 2). Settlement of C. magister was negatively correlated with upwelling indices ( 0 to $2 \mathrm{~d}$ lag) and salinity ( 0 to $2 \mathrm{~d}$ lag), and thus settlement increased as upwelling and salinity decreased. Most of Cancer magister settlement (86\%) occurred during relaxation events (Fig. 5), and especially during the first $14 \mathrm{~d}$ relaxation event $(72 \%)$, which may explain the significant cross-correlations with temperature, wind stress, and upwelling index. However, increases in settlement were apparent during subsequent relaxation periods (Fig. 4). The largest settlement peak occurred when surface currents in the region were moving predominately poleward (Fig. 3a). C. magister settlement also coincided with the decreases in salinity, which may account for the significant cross-correlation between settlement and salinity.
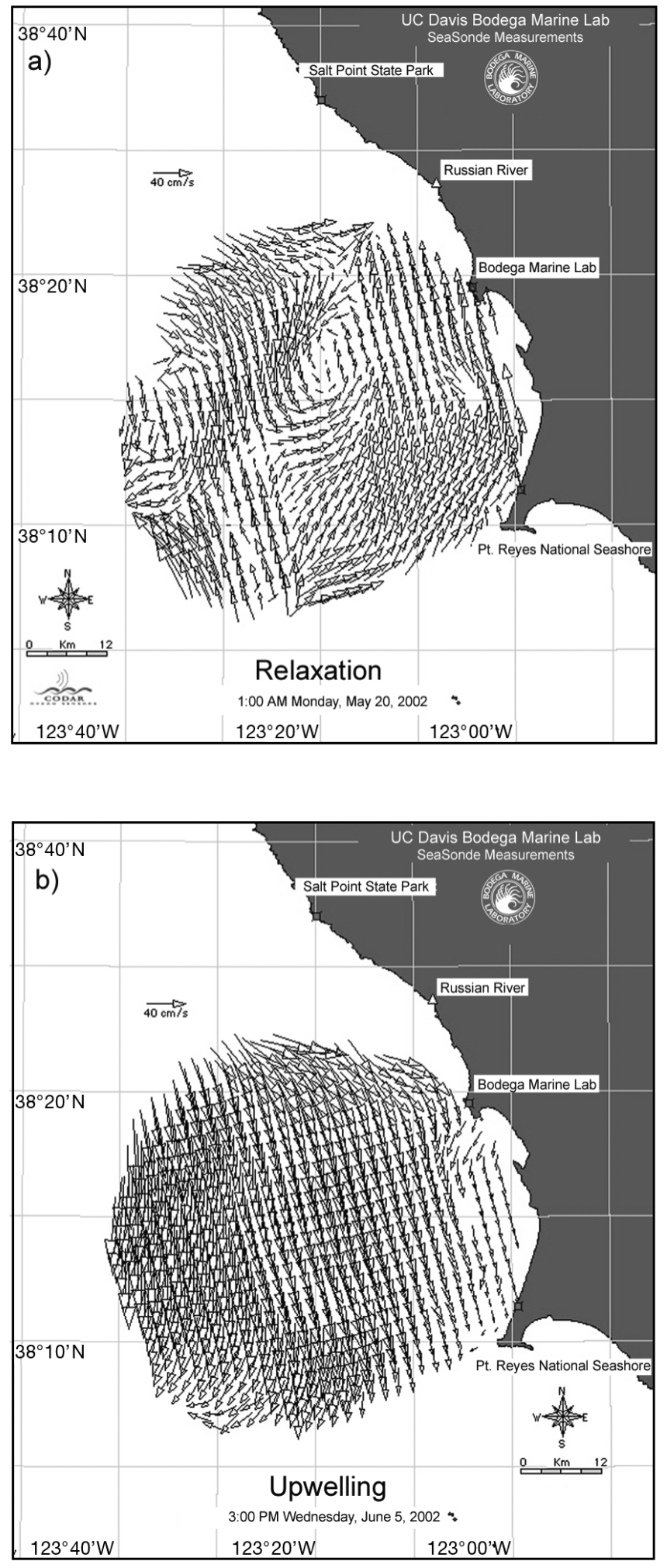

Fig. 3. High frequency radar data showing surface current speed and direction during (a) relaxation conditions with poleward flow during the Cancer magister peak settlement period and (b) upwelling conditions with equatorward flow during the Cancer antennarius/productus peak settlement period 
Table 1. Abundance of crab postlarvae collected at Pinnacle Rock in Bodega Bay. Abundance data are presented as total mean abundance $( \pm \mathrm{SE})$ over the $54 \mathrm{~d}$ sampling period (total average of collectors from 3 moorings, $\mathrm{n}=3$ ) and mean $( \pm \mathrm{SE})$ per sampling period (average of 3 collectors from each $2 \mathrm{~d}$ period, $\mathrm{n}=26)$. The percentage of total crab settlement ( $\%$ total) that each taxon represented and the percentage of trips ( $\%$ time) during the study that the taxa were present are also presented. Taxa in bold were used in analyses

\begin{tabular}{|llcrrr|}
\hline Taxon & Common name & Total mean & Mean trip & \% total & \% time \\
\hline Petrolisthes cinctipes & Porcelain crab & $1456.7 \pm 121.5$ & $56.0 \pm 9.7$ & 62.1 & 100 \\
Cancer antennarius/productus & Red crab/rock crab & $375.7 \pm 31.8$ & $14.4 \pm 3.5$ & 16.1 & 96.2 \\
Pagurus spp. & Hermit crab & $163.3 \pm 12.0$ & $6.3 \pm 1.1$ & 7.0 & 96.2 \\
Cancer magister & Dungeness crab & $80 \pm 6.0$ & $3.1 \pm 0.5$ & 3.4 & 84.6 \\
Hemigrapsus nudus & Shore crab & $71 \pm 4.0$ & $2.7 \pm 0.45$ & 3.0 \\
Petrolisthes eriomerus & Porcelain crab & $63 \pm 2.1$ & $2.4 \pm 0.37$ & 2.7 & 90.8 \\
Pugettia producta/richii & Kelp crab & $59.7 \pm 7.5$ & $2.3 \pm 0.52$ & 2.5 \\
Petrolisthes manimaculus & Porcelain crab & $18.7 \pm 4.4$ & $0.72 \pm 0.27$ & 0.8 \\
\hline
\end{tabular}

Hemigrapsus nudus were present in $80.8 \%$ of samples with $60 \%$ of total settlement occurring during upwelling conditions (Fig. 5). Settlement was positively cross-correlated with maximum tidal range (-2 to $-4 \mathrm{~d}$ lag) suggesting that they settled about 2 to $4 \mathrm{~d}$ before peak spring tides (Table 2).

Pagurus spp. postlarvae were present in $96.2 \%$ of samples, with 1 settlement event that occurred during upwelling conditions in May accounting for $24 \%$ of the settlement (Fig. 4). For Pagurus spp., 53\% of settled during upwelling favorable conditions (Fig. 5). Pagurus spp. settlement was negatively cross-correlated with surface water temperature (+4 to $6 \mathrm{~d}$ lag) and wind stress ( +4 to $6 \mathrm{~d}$ lag); settlement increased 4 to $6 \mathrm{~d}$ after sea water temperature decreased and equatorward (upwelling favorable) wind stress increased (Table 2).
Pugettia producta/richii were present in $88.5 \%$ of samples with $69 \%$ of total settlement occurring during upwelling (Fig. 5), including 2 settlement events in June, representing $55 \%$ of the total settlement (Fig. 4). Such pulses occurred during upwelling conditions when the winds were coming more from a westerly direction. Cross-shore wind stress was more positive (onshore) whereas alongshore wind stress became less negative (i.e. less equatorward) during settlement events (Fig. 2). These 2 settlement events may be responsible for a positive cross-correlation between settlement and cross-shore wind stress (0 to $4 \mathrm{~d}$ lag), which indicates that settlement increased 0 to $4 \mathrm{~d}$ after onshore wind stress increased.

Petrolisthes cinctipes were present in $100 \%$ of the samples (Table 1) and settled in the greatest abun-

Table 2. Cross-correlations between crab postlarval settlement and physical variables at Pinnacle Rock in Bodega Bay. Lags represent the sampling frequency of $2 \mathrm{~d}$ (a lag of $0=0$ to $2 \mathrm{~d} ; 1=2$ to $4 \mathrm{~d}_{i} 2=4$ to $6 \mathrm{~d}$ ). The sign indicates whether peaks in crab settlement occur after (positive values) or before (negative values) changes in the physical variables. Positive alongshore wind stress cross-correlations indicate a relationship between crab abundance and poleward winds (relaxation favorable), and negative cross-correlations indicate a relationship with equatorward winds (upwelling favorable). Positive cross-shore wind stress cross-correlations indicate eastward (onshore) wind and negative values indicate westward (offshore) wind. Positive maximum tidal range cross-correlations indicate a relationship with spring tides and negative values indicate neap tides. Values presented are statistically significant at $\mathrm{p} \leq 0.05 ; \mathrm{ns}=$ not significant

\begin{tabular}{|c|c|c|c|c|c|c|}
\hline & $\begin{array}{l}\text { Along-shore } \\
\text { wind stress }\end{array}$ & $\begin{array}{l}\text { Cross-shore } \\
\text { wind stress }\end{array}$ & $\begin{array}{l}\text { Upwelling } \\
\text { index }\end{array}$ & $\begin{array}{c}\text { Surface } \\
\text { temperature }\end{array}$ & Salinity & $\begin{array}{l}\text { Max. tidal } \\
\text { range }\end{array}$ \\
\hline $\begin{array}{l}\text { Cancer antennarius/ } \\
\text { productus }\end{array}$ & $+0=-0.569$ & ns & ns & $+0=-0.717$ & ns & ns \\
\hline Cancer magister & $+0=+0.558$ & ns & $+0=-0.412$ & $+0=+0.602$ & $+0=-0.560$ & ns \\
\hline Hemigrapsus nudus & ns & ns & ns & ns & ns & $-1=+0.498$ \\
\hline Pagurus nudus & $+2=-0.465$ & ns & ns & $+2=-0.413$ & ns & $\begin{array}{l}+2=-0.414 \\
+3=-0.420\end{array}$ \\
\hline $\begin{array}{l}\text { Pugettia productal } \\
\text { richii }\end{array}$ & ns & $\begin{array}{l}+0=+0.472 \\
+1=+0.507\end{array}$ & ns & ns & ns & $\mathrm{ns}$ \\
\hline Petrolisthes cinctipes & ns & $\mathrm{ns}$ & ns & ns & $+0=-0.753$ & $-2=+0.401$ \\
\hline Petrolisthes eriomerus & ns & ns & ns & ns & $+0=-0.630$ & $\begin{array}{l}+2=-0.406 \\
-2=+0.506\end{array}$ \\
\hline
\end{tabular}



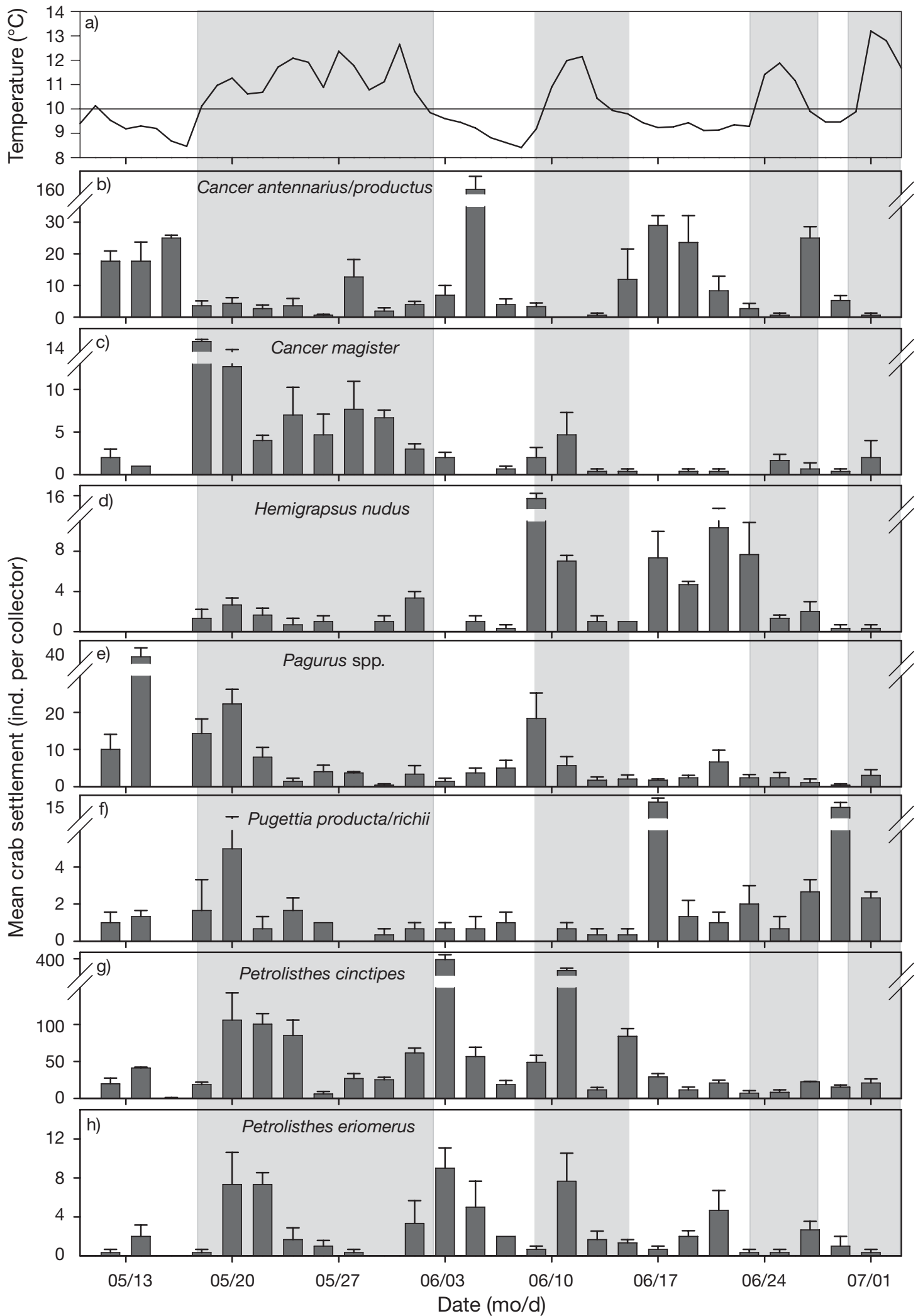

Fig. 4. Mean settlement $\pm \mathrm{SE}$ for each $2 \mathrm{~d}$ sampling period by 7 taxa relative to upwelling/relaxation cycles. (a) Temperature $\left({ }^{\circ} \mathrm{C}\right.$ ) with line at $10^{\circ} \mathrm{C}$ indicating transitions from upwelling $\left(<10^{\circ} \mathrm{C}\right)$ to relaxation $\left(>10^{\circ} \mathrm{C}\right)$ conditions. Shaded regions represent relaxation events. (b) Cancer antennarius/productus, (c) Cancer magister, (d) Hemigrapsus nudus, (e) Pagurus spp., (f) Pugettia producta/richii, (g) Petrolisthes cinctipes, and (h) Petrolisthes eriomerus. Note scale break in $y$-axis 

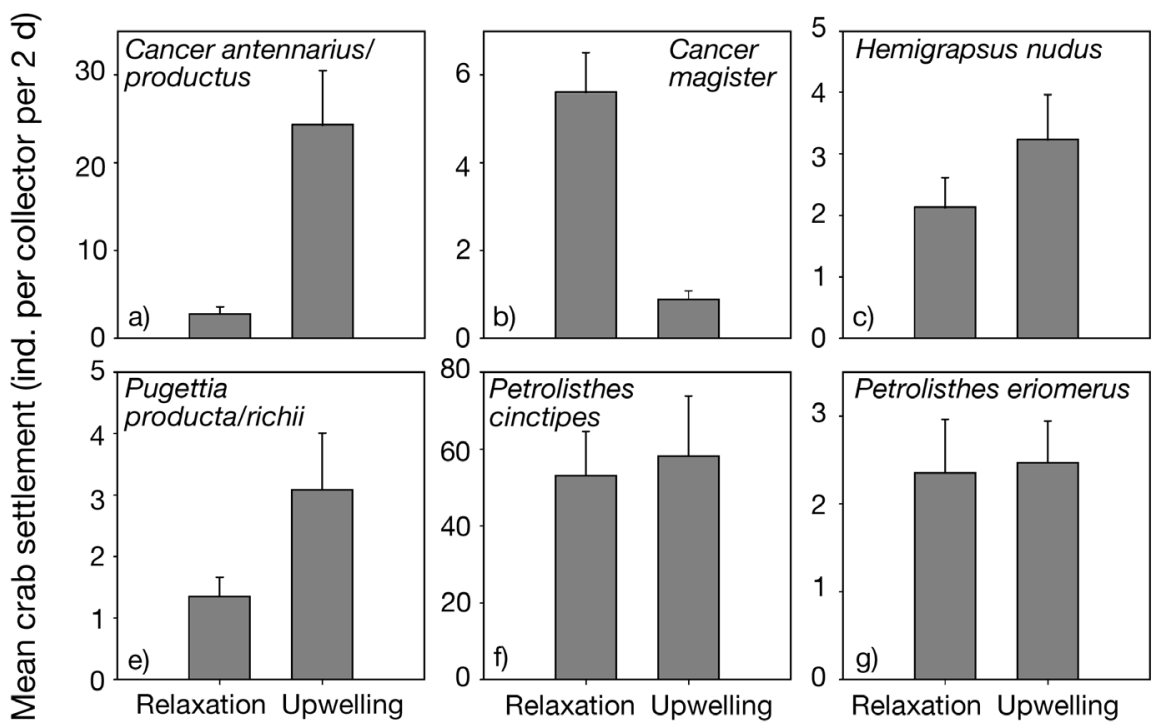

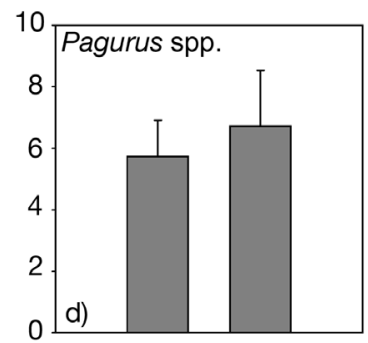

Fig. 5. Mean settlement \pm 1 SE during relaxation (mean $2 \mathrm{~d}$ temperature is $>$ $10^{\circ} \mathrm{C}$ ) and upwelling (mean $2 \mathrm{~d}$ temperature is $<10^{\circ} \mathrm{C}$ ). (a) Cancer antennarius/ productus, (b) Cancer magister, (c) Hemigrapsus nudus, (d) Pagurus spp., (e) Pugettia producta/richii (f) Petrolisthes cinctipes, and (g) Petrolisthes eriomerus dance $(1546.7 \pm 121.5, \mathrm{SE})$, representing $62.1 \%$ of total crab settlement. $P$. cinctipes abundance was negatively cross-correlated with salinity (0 to $2 \mathrm{~d}$ lag) and was positively cross-correlated with the maximum tidal range ( -4 to -6 d lag) suggesting that larvae of this species settled $4 \mathrm{~d}$ before peak spring tides (Table 2), particularly during low-salinity events.

Petrolisthes eriomerus was present in $92.3 \%$ of the samples. Settlement of this species was negatively cross-correlated with salinity (0 to $2 \mathrm{~d}$ lag) (i.e. settlement increased as salinity decreased) and was positively cross-correlated with maximum tidal range $(-4$ to $-6 \mathrm{~d}$ lag), suggesting that settlement occurred 4 to $6 \mathrm{~d}$ before peak spring tides (Table 2). P. eriomerus settlement was also negatively cross-correlated with maximum tidal range (+4 to $6 \mathrm{~d}$ lag) suggesting that they settled 4 to $6 \mathrm{~d}$ after neap tides (Table 2).

Petrolisthes manimaculus was present in $26.9 \%$ of samples and was not considered for analysis (Table 1). However, a qualitative examination showed that most of settlement occurred during 2 upwelling events in June.

\section{DISCUSSION}

\section{Interspecific differences in settlement timing}

The relative importance of larval transport mechanisms can vary among years (Wing et al. 2003) and regions (Johnson et al. 1986, McConnaughey et al. 1992, Roegner et al. 2003, Miller \& Shanks 2004). For example, recruitment of Cancer magister to light traps was positively correlated with upwelling events and tidal forcing in Oregon (Miller \& Shanks 2004). However, in Washington, C. magister recruitment to light traps was not significantly correlated with wind events or tidal forcing (Roegner et al. 2003). Here, we found that $C$. magister settlement was positively correlated with relaxation events, which is consistent with previous studies in this region (Wing et al. 1995a, Wing et al. 2003). Settlement of non-cancrid crabs was not as closely tied to upwelling-relaxation cycles. Therefore variation in settlement during upwelling or relaxation events for these species may have been coincidental and influenced more by other mechanisms (e.g. tidal processes or entrainment in an accumulation zone).

Settlement during 4 upwelling and 4 relaxation events in Bodega Bay was fairly continuous, with 7 of 8 species being present $>80 \%$ of the time. Regardless of oceanographic conditions, postlarvae settled continuously in the lee of this small headland, similar to patterns observed in the lee of Point Reyes (Wing et al. 1995a). Bodega Bay, in the lee of Bodega Head, has been identified as a larval accumulation zone (Mace \& Morgan 2006) due to a sub-surface recirculating eddy that sets up during active upwelling (Roughan et al. 2005). Larvae can be entrained in the recirculation feature and remain in the bay by undertaking diel vertical migrations (Roughan et al. 2005), which may help explain the continuous availability of settlers. While most species had 2 to 4 settlement peaks that represented a large portion of total settlement, settlement was typically continuous during the present study, suggesting that larvae of most species may be entrained in the lee of West Coast headlands throughout much of the settlement season.

Cancrid crabs had the strongest correlations with upwelling-relaxation cycles, whereby Cancer magister settled primarily during relaxation favorable conditions when surface currents are moving poleward, and 
C. antennarius/productus settled primarily during upwelling favorable conditions when surface currents are moving equatorward. Pugettia producta/richii and Pagurus spp. had weaker correlations with upwelling favorable conditions, which were likely due to 1 or 2 large settlement peaks that occurred during upwelling conditions. There was little difference between total settlement during upwelling and relaxation conditions for Hemigrapsus nudus, Petrolisthes cinctipes, $P$. eriomerus, and Pagurus spp. These results are similar to previous findings for non-cancrid crabs that were collected weekly in this region (Wing et al. 2003). Thus, peaks in settlements that are correlated with upwelling, relaxation, and tides provided evidence for multiple delivery mechanisms that varied within and among species.

Species with nearshore distributions and shorter larval durations may be more likely to be retained in headland eddies and more likely to be transported by tides. However, temperature and water flow data were treated extensively in a subsequent companion study in Bodega Bay and no clear evidence of internal wave activity was observed (Roughan et al. 2005). Although internal waves were not observed, Hemigrapsus nudus, Petrolisthes cinctipes, and P. eriomerus abundance increased 2 to $4 \mathrm{~d}$ prior to spring tides and Pagurus spp. abundance increased 4 to $6 \mathrm{~d}$ after neap tides ( 1 to $3 \mathrm{~d}$ before spring tides). Thus, evidence for tidal transport was apparent for all non-cancrid taxa except Pugettia producta/richii.

\section{Congeneric differences in settlement timing}

A $14 \mathrm{~d}$ relaxation event in May was the best example of increasing temperature and decreasing salinity in response to decreased alongshore wind stress. Wing et al. (2003) found that coherence among these variables was an important indicator of poleward transport of larvae from the lee of Point Reyes. Poleward alongshore flow began on 19 May (Fig. 3a) and continued until 1 June before it weakened and temporarily reversed. The majority of Cancer magister postlarvae settled during this relaxation period. While it is likely that many C. magister postlarvae were advected poleward from the lee of Point Reyes during this $14 \mathrm{~d}$ period, settler abundance increased rapidly as temperature increased suggesting that there was also a more local supply of postlarvae. For example, a large pulse of crabs settled during the $2 \mathrm{~d}$ period between 18 and 20 May as the temperature increased.

All significant cross-correlations for Cancer crabs had a lag of 0 ( 0 to $2 \mathrm{~d}$ ), which suggests that Cancer crabs settled with, or very soon after a change in wind stress or temperature. For example C. magister settle- ment increased during periods when temperature increased and $C$. antennarius/productus settlement increased during periods when temperature decreased. Wing et al. (1998) found higher concentrations of larvae residing in frontal zones between water masses, and crabs likely settle at the transition between warm and cold water as they are transported in the leading edge of warm or cold fronts. Temperature increased rapidly shortly after the cessation of the wind (Roughan et al. 2005), suggesting that a convergence zone between warm and cold water was not far from this site. Peaks in settlement coinciding with these changes in conditions may have resulted from fronts moving past the collectors because fronts are known to accumulate larvae (Roughgarden et al. 1991, Eggleston et al. 1998, Shanks et al. 2000, Sponaugle et al. 2002). The presence of larvae-laden fronts in the Bodega region may help to explain the settlement patterns in years where settlement is not correlated with the arrival of warm water from the lee of Point Reyes.

Depth distribution of different taxa may influence transport mechanisms. Larvae residing in bottom waters may be carried onshore during upwelling and larvae residing near surface waters may be carried onshore during relaxation events (Wing et al. 1995a) or via internal waves (Shanks 1998, Pineda 1999). Surface and bottom settlement data from 2001 and 2002 (Mace \& Morgan 2006) showed that while Cancer magister settled in greater abundance at the surface, C. antennarius/productus settled at both the surface and bottom. Further, peaks in C. magister settlement corresponded with increased temperature, suggesting that C. magister are delivered to shore via warm surface waters, whereas $C$. antennarius/productus settled during cold water events, indicating that $C$. antennarius/productus are transported onshore in cold nearbottom waters. C. antennarius/productus settlement was primarily observed inside Bodega Bay (Mace \& Morgan 2006), where recirculation at depth can accumulate larvae that spend time at depth (Roughan et al. 2005). In contrast, C. magister settlement occurred during relaxation, in the absence of recirculation, when warm waters delivered $C$. magister postlarvae to sites both within and outside the bay (Mace \& Morgan 2006).

This contrast in temporal and spatial patterns of settlement indicates that Cancer magister and C. antennarius/productus have adopted different coherent 'strategies' for the return of postlarvae to nearshore adult habitat. C. magister, with a longer planktonic larval duration and extended larval season, concentrate in fronts as postlarvae (Wing et al. 1998) and are delivered to the coast in warm waters from a nearby upwelling shadow (Wing et al. 1995b, Graham \& Largier 1997) or from offshore (Roughgarden et al. 
1988, Farrell et al. 1991, Roughgarden et al. 1991). In contrast, C. antennarius/productus, with shorter planktonic larval durations confined to the upwelling season, are delivered onshore as postlarvae in cold near-bottom waters during upwelling. Not only can this strategy maintain deep-dwelling C. antennarius/ productus larvae over the shelf, but it allows larvae to accumulate in the lee of small low-lying headlands where recirculation during upwelling may only be observed at depth.

Acknowledgements. This manuscript was improved through the expert help of J. Fisher, M. Holyoak, C. Lundquist, J. Largier, T. Grosholz, L. Botsford, J. Hare, and 3 anonymous reviewers. M. Holyoak provided invaluable help with statistics, J. Fisher with figures, and M. Roughan with physical data. We thank the numerous people who contributed countless hours to data collection and sample sorting, including, S. McAfee, M. Carver, T. Westman, V. Metcalf, J. Holbrook, M. Buckhorn, and A. Haring. We thank Bodega Marine Laboratory Marine Operations and the Gulf of the Farallones and Cordell Bank National Marine Sanctuaries for their logistical support. This work was funded by Sea Grant \# NA06RG0142 in collaboration with Loo Botsford and Jim Wilen, LernerGray American Museum of Natural History, University of California Natural Reserve System, University of California, Davis Graduate Group in Ecology, Golden West Women Flyfishers Foundation, and Challenges to California's Natural Resources. It is contribution number 2298 of the Bodega Marine Laboratory.

\section{LITERATURE CITED}

Botsford LW (2001) Physical influences on recruitment to California Current invertebrate populations on multiple scales. ICES J Mar Sci 58:1081-1091

Connell JH (1985) The consequences of variation in initial settlement vs. post-settlement mortality in rocky intertidal communities. J Exp Mar Biol Ecol 93:11-45

Connolly SR, Menge BA, Roughgarden J (2001) A latitudinal gradient in recruitment of intertidal invertebrates in the northeast Pacific Ocean. Ecology 82:1799-1813

Eggleston DB, Armstrong DA, Elis WE, Patton WS (1998) Estuarine fronts as conduits for larval transport: hydrodynamics and spatial distribution of dungeness crab postlarvae. Mar Ecol Prog Ser 164:73-82

Emery WJ, Thomson RE (2001) Data analysis methods in physical oceanography. Elsevier, Amsterdam

Farrell TM, Bracher D, Roughgarden J (1991) Cross-shelf transport causes recruitment to intertidal populations in central California. Limnol Oceanogr 36:279-288

Gaines S, Roughgarden J (1985) Larval settlement rate: a leading determinant of structure in an ecological community of the marine intertidal zone. Proc Natl Acad Sci USA 82: 3707-3711

Graham WM, Field JG, Potts DC (1992) Persistent 'upwelling shadows' and their influence on zooplankton distributions. Mar Biol 114:561-570

Grantham BA, Bjorkstedt E, Shkedy Y, Rosenfeld L, Roughgarden J (1995) The relationship between coastal upwelling convergence zones and zooplankton community composition. Bull Ecol Soc Am 76:97

Grantham BA, Chan F, Nielsen KJ, Fox DS, Barth JA, Huyer A,
Lubchenco J, Menge BA (2004) Upwelling-driven nearshore hypoxia signals ecosystem and oceanographic changes in the northeast Pacific. Nature 429:749-754

Grantham BA, Eckert GL, Shanks AL (2003) Dispersal potential of marine invertebrates in diverse habitats. Ecol Appl 13: S108-S116

Johnson DF, Botsford LW, Methot RDJ, Wainwright TC (1986) Wind stress and cycles in dungeness crab Cancer magister catch off California, Oregon and Washington USA. Can J Fish Aquat Sci 43:838-845

Kaplan D, Largier JL (in press) Surface transport of particles along the coast of Northern California derived from HF radar data. Deep-Sea Res II

Kingsford MJ, Leis JM, Shanks A, Lindeman KC, Morgan SG, Pineda J (2002) Sensory environments, larval abilities and local self-recruitment. Bull Mar Sci 70:309-340 (Suppl)

Large WS, Pond S (1981) Open ocean momentum flux measurements in moderate to strong winds. J Phys Oceanogr 11:324-336

Largier JL, Magnell BA, Winant CD (1993) Subtidal circulation over the northern California shelf. J Geophys Res 98: 18147-18179

Lough RG (1974) Dynamics of crab larvae (Anomura, Brachyura) off the central Oregon coast, 1969-1971. PhD dissertation, Oregon State University, OR

Lundquist CJ, Botsford LW, Diehl JM, Lee T, Lockwood DR, Morgan LE, Pearson EL (2000) Effects of El Nino and La Nina on local invertebrate settlement in northern California. CalCOFI Rep 41:1-10

Mace AJ, Morgan SG (2006) Larval accumulation in the lee of a small headland: Implications for the design of marine reserves. Mar Ecol Prog Ser 318:19-29

McConnaughey RA, Armstrong DA, Hickey BM, Gunderson DR (1992) Juvenile dungeness crab (Cancer magister) recruitment variability and oceanic transport during the pelagic larval phase. Can J Fish Aquat Sci 49:2028-2044

Menge BA (2000) Recruitment vs. postrecruitment processes as determinants of barnacle population abundance. Ecol Monogr 70:265-288

Miller JA, Shanks AL (2004) Ocean-estuary coupling in the Oregon upwelling region: abundance and transport of juvenile fish and of crab megalopae. Mar Ecol Prog Ser 271: $267-279$

Minchinton TE, Scheibling RE (1991) The influence of larval supply and settlement on the population structure of barnacles. Ecology 72:1867-1879

Parrish RH, Nelson CS, Bakun A (1981) Transport mechanisms and reproductive success of fishes in the California Current. Biol Oceanogr 1:175-203

Pineda J (1999) Circulation and larval distribution in internal tidal bore warm fronts. Limnol Oceanogr 44:1400-1414

Reilly PN (1983) Dynamics of Dungeness crab, Cancer magister, larvae off central and northern California. In: Wild PW, Tasto RN (eds) Life history, environment, and mariculture studies of the Dungeness crab, Cancer magister, with emphasis on the central California fishery resource. USGS, Menlo Park, p 57-84

Roegner GC, Armstrong DA, Hickey BM, Shanks AL (2003) Ocean distribution of dungeness crab megalopae and recruitment patterns to estuaries in southern Washington state. Estuaries 26:1058-1070

Rosenfeld LK (1990) Baroclinic semidiurnal tidal currents over the continental-shelf off northern California. J Geophys Res 95:22153-22172

Roughan M, Mace AJ, Largier JL, Morgan SG, Fisher JL, Carter ML (2005) Subsurface recirculation and larval retention in the lee of a small headland: a variation on 
the upwelling shadow theme. J Geophys Res Oceans 110: C10

Roughgarden J, Gaines S, Possingham H (1988) Recruitment dynamics in complex life cycles. Science 241:1460-1466

Roughgarden J, Pennington JT, Stoner D, Alexander S, Miller K (1991) Collisions of upwelling fronts with the intertidal zone: the cause of recruitment pulses in barnacle populations of central California. Acta Oecol 12:35-52

Send U, Beardsley RC, Winant CD (1987) Relaxation from upwelling in the Coastal Ocean Dynamics Experiment. J Geophys Res 92:1683-1698

Shanks AL (1998) Abundance of post-larval Callinectes sapidus, Penaeus spp., Uca spp., and Libinia spp. collected at an outer coastal site and their cross-shelf transport. Mar Ecol Prog Ser 168:57-69

Shanks AL (2001) An identification guide to the larval marine invertebrates of the Pacific Northwest. Oregon State University Press, Corvallis, OR

Shanks AL (2002) Internal tides and the biology of continental shelf waters. In: Castilla JC, Largier JL (eds) The oceanography and ecology of the nearshore and bays in Chile. Ediciones Universidad Catolica de Chile, Santiago, p 179-203

Shanks AL, Eckert GL (2005) Population persistence of California Current fishes and benthic crustaceans: A marine drift paradox. Ecol Monogr 75:505-524

Shanks AL, Largier J, Brink L, Brubaker J, Hooff R (2000) Demonstration of the onshore transport of larval invertebrates by the shoreward movement of an upwelling front. Limnol Oceanogr 45:230-236

Editorial responsibility: Jon Hare (Contributing Editor), Narragansett, Rhode Island, USA
Shkedy Y, Roughgarden J (1997) Barnacle recruitment and population dynamics predicted from coastal upwelling. Oikos 80:487-498

Sponaugle S, Cowen RK, Shanks A, Morgan SG and 7 others (2002) Predicting self-recruitment in marine populations: biophysical correlates and mechanisms. Bull Mar Sci 70: 341-375 Suppl

Strathmann MF (1987) Reproduction and development of marine invertebrates of the northern Pacific Coast. University of Washington Press, Seattle, WA

Wing SR, Botsford LW, Largier JL, Morgan LE (1995a) Spatial structure of relaxation events and crab settlement in the northern California upwelling system. Mar Ecol Prog Ser 128:199-211

Wing SR, Largier JL, Botsford LW, Quinn JF (1995b) Settlement and transport of benthic invertebrates in an intermittent upwelling region. Limnol Oceanogr 40:316-329

Wing SR, Botsford LW, Ralston SV, Largier JL (1998) Meroplanktonic distribution and circulation in a coastal retention zone of the northern California upwelling system. Limnol Oceanogr 43:1710-1721

Wing SR, Botsford LW, Morgan LE, Diehl JM, Lundquist CJ (2003) Inter-annual variability in larval supply to populations of three invertebrate taxa in the northern California Current. Estuar Coast Shelf Sci 57:859-872

Yoklavich MM, Loeb VJ, Nishimoto M, Daly B (1996) Nearshore assemblages of larval rockfishes and their physical environment off central California during an extended El Nino event, 1991-1993. Fish Bull 94:766-782

Submitted: August 15, 2005; Accepted: January 27, 2006 Proofs received from author(s): September 25, 2006 